\title{
Comparative law and equivalence assessment of system-bound terms in EU legal translation
}

\author{
Anna Jopek-Bosiacka
}

University of Warsaw, Poland

a.jopek-bosiacka@uw.edu.pl

Legal translation is not only inter-lingual translation, but also a translation of and between various legal systems. Many translation problems may be solved by having reference to comparative law. This is especially critical in the European Union, whose policy of multilingualism and striving towards the principle of equal authenticity in law leads to something close to mission impossible: the reconciliation of the 28 legal systems of its member states into a coherent body of law which would ensure uniform interpretation of EU legal texts. The aim of this paper is to describe legal translation strategies in general, and illustrate them using English-Polish official translations of system-bound terms of the case law of the European Court of Justice. The analysis will focus on several vital concepts of common law, such as 'equity', 'consideration', 'trust', 'misrepresentation', and 'tort'; terms which are mostly absent in the Polish legal system. Comparative law will serve as a tool for the quality assessment of legal translation and evaluation of the equivalence of legally adequate terms.

\section{Introduction}

Legal language is strictly tied to a national legal system. Legal translation, however, is not only a translation between languages, but also a translation of and between various legal systems. The separate developments of these various legal systems and separate sets of legal concepts and terminology account for the major translation problems in legal translation. Many of these problems can be identified and solved by referring to the findings of comparative law, treated as the systematic study of particular legal traditions and legal rules on a comparative basis.

The importance of comparative law has recently increased due to the developments in international trade and the tendency towards harmonization of laws within both international and supranational bodies, of which the European Union is one. Translation in the European Union institutions, restricted by the principles associated with multiligualism as laid down in Article 24 of the Treaty on the Functioning of the European Union (TFEU) and Council Regulation 1/1958, requires complicated 
resources (translation databases, mutually designed glossaries. etc.) to ensure cooperation between translators, drafters, experts and administrators. At the European Court of Justice (ECJ) it is even more complicated, as all the texts are operative legal texts and can only be translated by qualified lawyer-linguists. Their translation must not only cover combinations of the 24 official languages of the European Union, but also reconcile the different legal systems of the member states.

The aim of this paper is to describe some problems arising in legal translation and solutions adopted to resolve them on the basis of ECJ case law and its official Polish version. The analysis will focus on several vital concepts of common law, such as 'equity', 'consideration', 'trust', 'tort', and 'misrepresentation', which are mostly absent in the Polish legal system. Firstly, the strategies adopted in English-Polish translations of such system-bound concepts will be described. Secondly, the strategies will be analyzed within the framework of comparative law methodology. Comparative law will thus serve as a tool for the quality assessment of legal translations, i.e. evaluation of legally adequate equivalents.

The unique EU policy of multilingualism can be expected to produce special solutions in legal translation in order to ensure the uniform interpretation and application of ECJ judgments, which can be undermined by the EU's policy of linguistic diversity. The results may only be assessed with the help of comparative law, because the principle of equal authenticity makes it impossible to refer to an 'original version' in case of any linguistic doubt, since all the language versions are treated as original. Additionally, the ECJ adopts specific rules of interpretation (mainly teleological and literal), which need to be considered in the process of translation as well. Also inter-institutional guidelines, designed to improve the quality of EU legislation and case law in the long run, aim to ensure their uniform interpretation by devising consistent formats for documents of the same type. The question remains if such "translationfriendly" texts are not false friends to a lawyer-linguist, and if this arduous task of examining the scope of legal terms from incongruent legal systems requires reference to the comparative law approach.

\section{Comparative law in legal translation}

As has been pointed out, differences between legal systems are the major source of difficulty in legal translation, because the language of law is not a universal legal language, but one tied to a national legal system (Weisflog, 1987, p. 203; cited after Cao, 2007a, p. 23). The legal languages of different countries over the process of their long and incremental development have been heavily influenced by the history and culture of a particular state. These differing components have in turn led to the emergence of diverse and often contrasting legal concepts, norms, institutions, and - of key importance to a legal translator - differing 
linguistic structures. Even if the same language is used in numerous legal systems (as in the case of English, German, or Spanish), there are still linguistic and legal differences between the conceptual frameworks. Thus the concepts, even if similar, do not always have the same precise meaning (see Brand, 2009, p. 22; Jopek-Bosiacka, 2011; Kischel, 2009, p. 7; Šarčević, 1997).

Legal systems have different sources of law and legal terminology, as well as differing conceptual, social and cultural bases. All of these elements lead to a lack of equivalent terminology across legal languages, and these systemic differences are the major source of difficulty for translators. A comparison of the two major legal systems, common law and civil law, reveals differences in sources of law, modes of reasoning and legal ideologies, which have been collectively labelled as the 'style' of a legal system (Zweigert \& Kötz, 1977, p. 62; cited after de Cruz, 2007, p. 30).

\subsection{Defining comparative law}

'Comparative law' is a highly complex and debatable notion in terms of its name, object, purpose and nature (see Brand, 2009, p. 19; de Cruz, 2007, pp. 1-10; Glendon, Gordon, \& Osakwe, 1985, pp. 1-38; Kischel, 2009 , p. 8). Conventionally, it is defined as a scholarly study of the similarities and differences between the legal systems of different jurisdictions, such as between civil-law and common-law countries. ${ }^{1}$ As de Cruz (2007) points out, "[c]omparative law is, therefore, primarily a method of study rather than a legal body of rules" (p. 5).

The importance of comparative law for translation lies in its effectiveness as a tool for comparing various legal systems and identifying their differences/similarities. Many legal translation problems can thus be identified by way of referring to the findings of comparative law and its 'common core research' method, aimed at searching for the common denominator in various substantive law areas (de Cruz, 2007, p. 26; see also Holland \& Webb, 2006, pp. 323-326, on analytical techniques employed by European lawyers).

The European Court of Justice of the European Union utilizes the comparative law method in interpreting EU law and seeking to reach sound judgments by evaluating solutions provided by various legal systems (de Cruz, 2007, p. 26; and the list of cases cited therein).

\subsection{Comparative study of judicial styles}

"The law in a given country reflects the style of its judgments, and this style reflects the law" (Kischel, 2009, p. 14). Different writing styles require different hermeneutics (Grossfeld, 2003, p. 166; quoted after 
Brand, 2009, p. 21; see also Holland \& Webb, 2006, pp. 124-127, on how a judicial style may affect the way in which facts are used).

Not surprisingly thus, the style of judgments issued is also markedly different. Following Wetter (1960), Peter de Cruz (2007, pp. 254-266) distinguishes five main styles of judgments: English, French, German, Swedish, and American. ${ }^{2}$ Irrespective of the style, there are general cross-cultural differences between judgments, reflecting the basic comparative law classification of legal systems into common law and civil law families or traditions. Common law judgments follow the argumentative model and are written like a dissertation. They lack the formal restraints of civil law judgments, many of which still follow the French tradition of formulating the entire judgment in a single sentence (Łętowska, 1997, pp. 3-4 ; Šarčević, 1997, p. 123). The French model of legal justification as cognitive model (from facts to legal consequences) was much influenced by the French school of hermeneutic exegesis (Kozak, 2002, p. 111). Between the two types is an intermediate German model, which focuses on legal scholarship and judicial decisions (Łętowska, 1997, pp. 3-4; see also the detailed analysis in de Cruz, 2007, pp. 262-266).

Of vital importance for our discussion are two judgment types used by various EU member states, referred to as English and French. The most rigid form requirements in legal drafting can be found in judgments following the traditional French style (Lashöfer, 1992, p. 44). Formulated in one sentence, with each set of reasons introduced by the conjunction attendu que in the higher courts and considerant que in the lower courts, such judgments are particularly suitable for expressing rigid, Latin logic (Mimin, 1978, p. 185; Wetter, 1960, p. 28). The French tradition of formulating judgments in one sentence was adopted by some German courts during the reception of French law in the nineteenth century, but was later replaced by the more flexible method of presenting the judgment in the form of a dissertation, with headings for each section (Šarčević, 1997, p. 123). In Europe, the French style of judgments is still used in France, Belgium, Luxembourg, Finland, Portugal, and Spain (see David \& Brierley, 1985, p. 142). Polish judgments also follow the French technique, irrespective of their length.

On the other hand, common law courts follow the dissertation style. The English court communicates its decision on the case before it in the form of an order to the parties. Lawyers, however, are interested in the court opinion of the case. Court opinions are pieces of advocacy in which the courts explain their rulings. The courts want the reader to accept the ruling as the inevitable outcome of that legal dispute (Brostoff \& Sinsheimer, 2000, p. 53). American judgments in particular usually constitute a polemic against the arguments of the losing party (Lętowska, 1997, pp. 3-4). The style of English judgments also tends to be individual. Some judges adopt a clear narrative pattern, others have a more formal style. A more recent innovation is to break up the text with 
headings and subheadings, which improves the clarity of the judgment. It is also now the normal practice that paragraphs are numbered continuously throughout the published version of the judgment (Holland \& Webb, 2006, p. 79).

Judgments at the European Court of Justice in Luxembourg have a uniform format and style that can be described as a hybrid of the French technique and the more flexible dissertation method (Berteloot, 1988, p. 13). The body of the judgment consists of only two parts: the recital of the parties and the decision (reasons + operative part), while the introductory materials include the summary (key words + synopsis), report of the hearing (facts and issues), and the non-binding opinion of the Advocate General (Šarčević, 1997, p. 125). Admittedly, the ECJ does not determine the cases themselves, nor does it apply the law to the facts: it makes rulings on interpretation, not decisions on who wins or loses the case. Judgments are short and often without detailed reasons (Holland \& Webb, 2006, p. 313, p. 320, p. 328). As ECJ judgments are collegial, no individual voices of particular judges are heard and there is no provision for dissenting opinions. Unlike English judgments, an ECJ judgment is presented in the form of numbered paragraphs, (although this practice has been recently adopted by English courts as well). The actual ruling of the Court appears at the end of the judgment. It is usually quite short, and is identified by the opening phrase 'On those grounds...' (in the English version, in the French it is 'pour ces motifs . ..') (Holland \& Webb, 2006, pp. 85-86).

The contents of ECJ judgments reflect the legal cultures involved and assumptions about the judicial function (see section 3), as has been noted by James Holland and Julian Webb (2006, p. 86). The judgments are presented in a logical, developmental form, which reflects a point by point, rational, deductive process of reasoning. They are relatively easy to read, but points of uncertainty or argument are rather absent, and the Court does not explore ramifications beyond the issues directly raised by the case at hand.

Regardless of style, we may assume that in the Euro-Atlantic legal culture (i.e., European and Anglo-Saxon) it is expected that a legal decision is not arbitrary; that is, that it is justifiable by underlying 'good reasons' (Dascal \& Wróblewski, 1991, p. 429). Therefore, the parts of a judgment are organized more or less in the form of a syllogism, which reflects the basic rationale of the judicial decision (Bocquet, 1994, p. 34). Greatly simplified, the process of judicial decision can be described as follows: after identifying the issues or questions of law (major premise) and establishing the facts of the case (minor premise), the judge applies the law to the facts, reaching a conclusion of law (conclusion) on which the final decision is based (see Walker, 1980, p. 673).

Irrespective of cultural differences in judgments and various judicial styles, judgments, like other legal genres, are subject to rationality assumptions, which are reflected in their overall textual 
structure (Jopek-Bosiacka, 2010, p. 157). Legal discourse is a prime example, where communicative rationality and legal reasoning have been institutionalised and bound by more or less explicit norms. Following Dascal and Wróblewski (1991, p. 422), we may possibly speak of an 'axiology of legal communication', presupposing a certain form of rationality.

A convergence of legal and judicial styles is continually taking place, albeit to a limited extent, owing to the unique ideological, procedural, linguistic, methodological and conceptual differences of various legal systems (de Cruz, 2007, p. 270).

As far as Europe and the countries of the European Union are concerned, however, if a high degree of harmonization of European law becomes a reality, comparative law scholars will relish the fascinating prospect of seeing the development of a unique blend of law, a twenty-first-century European ius commune reflecting international and national judicial styles, emerging from the melting pot of common and civil law judicial traditions. (de Cruz, 2007, p. 271)

\section{The European Court of Justice}

The European Court of Justice of the European Union (ECJ) in Luxembourg is the judicial institution of the European Union. It consists of three courts: the Court of Justice, the Court of First Instance, and the Civil Service Tribunal. Its mission, according to its official site (http://curia.europa.eu/jcms/jcms/Jo2_6999/, accessed on 20 March 2013), is to ensure that "the law is observed in the interpretation and application" of the Treaties. In particular, the ECJ reviews the legality of the acts of the institutions of the European Union, ensures that the Member States comply with their obligations under the Treaties, and interprets European Union law at the request of national courts and tribunals. The Court's task is to provide for the proper and final uniform application and interpretation of European Union law.

The ECJ case-law, i.e. decisions made and recorded in certain types of texts, enables lawyers and interested persons to establish the principles crucial to the functioning of the European Union, such as the principle of direct effect of EU law, or the principle of primacy of EU law.

The Court of Justice is composed of 28 judges appointed by the Member States for a renewable period of six years. The judges are supported by eight Advocates General. These Advocates are responsible for presenting an 'opinion' in the cases assigned to them. The Court may sit as a full court, in a Grand Chamber of 15 judges, or in chambers of three or five judges. 
There are several types of proceedings, which include references for preliminary rulings, actions for failure to fulfil obligations, actions for annulment, actions for failure to act, appeals and review. All of these are explained in detail in the official Court website at http://curia.europa.eu/jcms/jcms/Jo2_7024/, accessed on 2 July 2013.

The procedure before the ECJ usually consists of two stages: written and oral (if appropriate), the latter of which is public. An action before the Court must be brought by an application addressed to the Registry. The Registrar publishes a notice of the action in the Official Journal, setting out the applicant's claims and arguments. At the same time, the application is served on the opposing party (defendant), who has one month within which to lodge a defence. The applicant may then lodge a reply and the defendant a rejoinder, the time allowed being one month in each instance. A Judge-Rapporteur and an Advocate General, responsible for monitoring the progress of the case, are appointed by the President and the First Advocate General respectively.

When it has been decided that an oral hearing will be held, the case is argued at a public hearing before the bench and the Advocate General. The Judges and the Advocate General may put any questions to the parties which they consider appropriate. Some weeks later, the Advocate General delivers his or her Opinion before the Court of Justice, again in open court. He or she analyses in detail the legal aspects of the case and suggests, completely independently to the Court of Justice, the response which he or she considers should be given to the problem raised. This marks the end of the oral stage of the proceedings. If it is decided that the case raises no new question of law, the Court may decide, after hearing the Advocate General, to render a judgment without an Opinion.

To prepare their collective judgment, the Judges deliberate on the basis of a draft judgment drawn up by the Judge-Rapporteur. Each judge may propose changes. Decisions of the Court of Justice are taken by majority and no record is made public of any dissenting opinions. Judgments are signed by all the Judges who took part in the deliberation and the operative part of the judgment is pronounced in open court. Judgments and the Opinions of the Advocates General are available on the CURIA Internet site on the day they are delivered. They are, in most cases, subsequently published in the European Court Reports.

\subsection{Interpretation of EU documents by the European Court of Justice}

The two underlying principles concerning the status of different languages are the principle of equality and principle of the equal authenticity of all language versions of European documents. These principles were introduced in the Treaty establishing the European Community (1957). The courts were burdened with the additional task of 
comparing language versions and looking for the underlying meaning common to all: "... if one or more meanings is broader than the other(s), the meaning signifying the lowest common denominator of all the texts should prevail" (Šarčević, 1997, p. 198).

In multilingual jurisdictions different language versions of documents are treated as equivalent, but this principle of equal authenticity must, to some extent, be based on a legal fiction (Cao, 2007b, p. 73). Legal documents are treated as identical in meaning irrespective of the fact that they use different languages. The legal fiction involves treating words and phrases in different languages as having an identical meaning. Despite the uncertainty of the language, law demands certainty and this legal fiction is needed so that citizens will be treated identically when governed by separate linguistic versions in a multilingual legal system.

Considering the principles of language equality and the authenticity of all language versions of EU documents, in cases of doubt or dispute it is not possible to refer to an 'original version'. In such an event a dispute may be referred to the ECJ, whose task is to ensure the uniform interpretation and application of the EU legislation in every Member State.

The civil law approach to statutory interpretation, and that of the ECJ also, is 'purposive', emphasizing simplicity of drafting and a high degree of abstraction as opposed to the common law tradition (Holland \& Webb, 2006, p. 342). In considering questions of interpretation, the European Court of Justice may choose from literal, contextual, comparative and teleological methods, discussed below.

The literal interpretation involves a linguistic analysis of the text and may involve a comparison of different language versions. An adherence to the literal approach by the ECJ may therefore become difficult because of the multilingual nature of EU law.

The contextual approach, like the literal approach, concentrates upon the meaning of words, except it does not confine itself to the wording of a particular act, but rather considers the whole legislative context. The ECJ must then consider the framework of the entire EU law, that is, the interrelations of all aspects of EU law (Holland \& Webb, 2006, p. 344).

In a comparative approach, the ECJ judges will seek to evaluate and utilize solutions provided by the legal systems from which its judges are drawn (see examples in Holland \& Webb, 2006, p. 344). This approach is interrelated with analogical reasoning.

The last and most important approach is the teleological method, understood as a broad 'purposive' method which requires ECJ to view legislation taking into account the entire setting and spirit of the acquis communautaire. As Holland and Webb (2006, p. 344) note, this method is widely used by the ECJ and increasingly employed by national courts in interpreting EU law. 


\subsection{Translation procedures at the ECJ}

The Court of Justice of the European Union is a multilingual institution. Each of the official languages of the European Union can be the language of a case. In direct actions, the language used in the application (which may be one of the 24 official languages of the European Union) will be the 'language of the case', that is, the language in which the proceedings will be conducted. With references for preliminary rulings, the language of the case is that of the national court which made the reference to the Court of Justice. Oral proceedings at hearings are interpreted simultaneously, as required, into the various official languages of the European Union. The judges deliberate, without interpreters, in a common language which, traditionally, is French (its internal working language).

The unit responsible for translation at the ECJ is the DirectorateGeneral for Translation. All the documents handled by the ECJ are translated by legally qualified translators with a degree in law and a thorough knowledge of at least two foreign languages (so-called lawyerlinguists), according to Article 22 of the Court's Rules of Procedure. In addition to their translation work, all lawyer-linguists perform other tasks: legal analysis in collaboration with the registries and other services of the Court (including the drafting of summaries of certain requests for preliminary rulings), and terminological research or collaboration with lawyer-linguists of other language units on questions of national law.

At various stages the case may be formulated in various languages. The provisions concerning language arrangements for proceedings before the Court of Justice are set out in Articles 29 to 31 of its Rules of Procedure. The language of the case is determined for each action. In preliminary ruling proceedings, the language is always that used by the national court or tribunal which made the reference. In direct actions, applicants may choose the language of the case. They are not bound by their own nationality or by that of their lawyer. However, where the defendant is a Member State the language of the case is the language, or one of the official languages, of that State. Once the language of the case has been determined, it must be used throughout the proceedings, both in the written and oral procedures. The choice of the language to be used is binding not only on the parties, but also on any third parties who may be granted leave to intervene.

Advocates General, however, usually use their own language, and their Opinions are translated from the original text into the language of the case for the parties, and into all other languages for publication. Since references for preliminary rulings from national courts are notified immediately to all the Member States, they have to be translated into all the official languages as well.

The common language used by the Court in deliberations is, as already stated, French - by custom. Thus, all documents lodged by the 
parties in the language of the case are translated into French as part of the internal working file. However, documents exchanged between the registries and parties are in the language of the case. This assumes particular importance at the end of the proceedings, since the only authentic version of the judgment handed down by the Court of Justice is that which appears in the language of the case. The judgments of the Court of Justice are published in the European Court Reports, which appear in all the official languages.

The fact that ECJ judgments are for the most part translations has certain implications for their interpretation and application (see also McAuliffe, 2009).

\section{EU multilingualism and legal translation}

The establishment and development of the European Union sheds a new light on legal translation. The difficulties of legal translation already discussed, (i.e., translating concepts of incongruent legal systems), are further complicated by the equal authenticity and equality principles, the increasing number of official EU languages, and the principle of multilingualism. Multilingualism, as established by Regulation 1/1958, enables every citizen of the EU to address the European institutions in his or her own language and receive an answer in that language.

In order to achieve uniformity in law, EU institutions apply numerous solutions: they devise consistent formats for documents, prepare and publish sets of guidelines for translators, and create extensive databases. Having a similar aim, legal translators - with the help of comparative law methods - adopt the following strategies and techniques (Alcaraz Varó \& Hughes, 2002, pp. 184-185; Šarčević, 1988, pp. 456459):

- $\quad$ search for functional equivalents, that is, terms in the target language which denote a concept in the target legal system of the same or similar function as the source language concept. In order to explain the nature of the source text term and provide a neutral and broad target language equivalent, translators frequently choose descriptive equivalents;

- $\quad$ use of borrowings and naturalizations to express, for instance, national institutions or national administrative units (cf. Attachment to the Polish Guidelines for EU Translators Vademecum Ttumacza version 10, December 2012 available at http://ec.europa.eu/translation/polish/guidelines/documents/stylegu ide_polish_dgt_pl.pdf) or system-bound terms with no equivalent (e.g. the certification of five distinct legal professions in Poland);

- $\quad$ use of literal equivalents to enable the recipients to grasp a general idea of the notion and associate the term or the notion with the 
institution the recipient is familiar with in his/her own legal system. Clarification of a term is possible by means of an additional word, notes or glosses to guide the recipient. Sometimes couplets are used, that is, citations of the source text in parenthesis, preceded by the literal equivalent;

- use of the technique of transposition, that is, replacing one grammatical category with another while preserving the semantic value of an element;

- $\quad$ use of the technique of expansion, that is, adding an element to the translated item in the target language, where a literal translation would leave some doubt as to the actual scope of the lexical item in question;

- $\quad$ use of the technique of modulation, which involves changes to semantic processes, for example, when interpreting English judges whose language is more colloquial and metaphoric than that of continental judges.

Ideally, the translator should search for functional equivalents, and only in cases where there are none should resort be made to other techniques and solutions.

Section 4.2. will be devoted to an empirical analysis of the strategies employed by lawyer-linguists of the European Court of Justice in English-Polish translation.

\subsection{Comparative law method in legal translation}

"Any form of translation runs the risk of overlooking the conceptual differences between languages," notes Peter de Cruz (2007, p. 220). Difficulties increase when translating alien legal concepts from incongruent legal systems, such as the Anglo-Saxon concepts of 'consideration' or 'trust' into Polish. Traditionally, cross-cultural differences between legal systems must be observed and their comparability is subject to various factors which are beyond the scope of our discussion (see de Cruz, 2007, pp. 222-231; Jopek-Bosiacka, 2010).

It should be noted parenthetically that EU law integrates the various legal systems of its member states (of vital importance would seem to be French law and common law) and as such requires the application of a "comparative literal interpretation" (see Mik, 2000, p. 684, p. 691).

For the purpose of this research one dimension of comparative studies seems particularly useful, namely 'micro-comparison'. The term has been attributed to M. Rheinstein (1968; as cited by de Cruz, 2007, pp. 233-234). 'Micro-comparison' generally refers to the study of topics or aspects of two or more legal systems. Among the possible topics, de Cruz enumerates (2007, p. 234) topics such as: 
- $\quad$ the institutions or concepts peculiar to particular legal systems;

- the sources of law, judicial systems and judiciary, legal profession or even the structure of the legal system;

- $\quad$ the various branches of national/domestic law;

- $\quad$ the historical development of legal systems; and

- $\quad$ the ideological, socio-legal and economic bases of that system.

In order to evaluate the comparability or equivalence of compared items, the purpose of the particular comparison must be determined, and various requirements of systematic comparison fulfilled, as noted by de Cruz (2007, p. 234). For the purposes of a comparative study of legal phenomena or systems, a knowledge of the socio-cultural factors, including context, is required. "Naturally, the fewer common denominators there are between the systems being compared, the greater the detailed background or socio-cultural knowledge that will be required" (de Cruz, 2007, p. 236).

Following Zweigert and Kötz (1977), the basic methodological principle of all comparative law is that of functionality, from which other rules stem. Comparatists can then compare how institutions having the same role in different legal systems fulfil the same particular function (de Cruz, 2007, p. 237).

Among possible methods of comparison - defined as methods of obtaining, ordering, and measuring data - Orücü (2006, p. 446) lists observation, documentary research, sample surveys, statistical operations, context analysis, and in-depth interviews. Kamba (1974; cited after de Cruz, 2007, p. 240) suggests that three stages are involved in the process of comparison, namely description, identification, and explanation. The descriptive phase can take the form of a description of the norms, concepts and institutions of the systems concerned. The identification phase deals with the identification of differences and similarities between the compared systems. In the explanatory phase an attempt is made to account for the resemblances and dissimilarities between systems, concepts, and institutions.

For the purpose of our analysis we have selected for microcomparison the legal institutions and concepts peculiar to a common law system and describe them against authoritative source(s) of legal literature, to see if there are any differences or similarities between the compared systems.

\subsection{Equivalence of system-bound terms in English-Polish translations of ECJ judgments}

This section contains explanations of the meaning of selected common law terms and an analysis of their equivalents used in the official Polish translation of the European Court of Justice judgments. Due to the 
incongruence between Polish (civil law) and English (common law) legal systems, a perfect equivalence of system-bound terms cannot be reached.

In fact the use of English in Continental (EU) legal contexts promotes in many cases 'system-neutral senses' of traditional English law terms, senses which may be rare in classical common-law contexts, as in the case of 'equity' (Mattila, 2013, pp. 348-349).

Hence, this analysis will focus on solutions adopted in translation, depending on the context and sentence structure. The results are presented in the form of tables, containing a field for the Polish equivalent, context in which the term appears in the Polish sentence, back translation of the analysed term/expression, and a reference to the case number and name. The analysis of each term's equivalents is preceded by an explanation of the original term's meaning and nature from Black's Law Dictionary (1999) and the Oxford Dictionary of Law (1994).

\subsubsection{Equity}

Black's Law Dictionary (1999, p. 560) offers nine definitions for 'equity', of which some are relevant for purposes of comparison:

- fairness, impartiality and even handed dealing;

- the body of principles constituting what is fair and right; natural law;

- the recourse to principles of justice to correct or supplement the law as applied to particular circumstances, e.g deciding the case by equity;

- the system of law or body of principles originating in the English Court of Chancery and superseding the common and statute law when the two conflict.

Today equitable jurisdiction is used in trusts, equitable interests in property, relief against forfeiture and penalties, and equitable remedies (Oxford Dictionary of Law, 1994, p. 147).

However, the examples in Table 1 show that the ECJ has chosen not to refer specifically to the English legal concept of equity, but rather refers to a term of Latin origin - 'aequitas', which is expressed in German as 'Billigkeit', in French as 'équité', and in Polish as "słuszność", while in English it conveys the meaning of "natural justice" or "fairness" associated with the national word variant of 'aequitas', that is, equity. Legal English has thus conserved this original Latin meaning, while expanding the concept to include other technical common-law applications, such as "the system of law or body of principles originating in the English Court of Chancery." These peculiarly English concepts are excluded in ECJ judgments. 
Even early Polish studies on the doctrine of "equity", such as those by Henryk Piętka (1929) or Leon Konic (1947), underline differences in understanding "equity" between common law and civil law legal systems. Piętka (1929) treats "słuszność" as one of the legal normative facts, that is, one of the sources of law: "jus aequum"/"billiges Recht (p. 249) and distinguishes between three types of such "jus aequum" originating in England: "statutory equity law" ("prawo słuszne kodeksowe/ustawowe"), "default equity law" (in instances where no positive law applies - "prawo słuszne obrotowe"), and "prawo słuszne sądowe" ("judicial equity law") (Piętka, 1929, pp. 251-253). Interestingly, he claims that the notion of "jus aequum" evolved differently in Roman law and in common law. In Roman law it was default equity law (in instances where positive law was not applicable), whereas in English law it evolved into a judicial or judgemade law of equity. Thus, the Roman equivalent of 'equity' ("jus aequum") was the English version of common law, not equity law (Piętka, 1929, p. 270). In continental legal systems following Roman law traditions, the equity element in its natural law meaning was in practice replaced with statutory and case laws, whereas in England the equity element is still present in understanding the role of a judge as being able to create legally applicable rules (Piętka, 1929, pp. 271-272).

It needs to be noted that the notion of 'equity' in the judgments issued by the European Court of Justice and translated into Polish are mostly translated from French, the working language of the Court (see also comments on the untranslatability of the term 'equity' into German in Brand, 2009, pp. 23-24). As French judgments are simultaneously translated into all the other EU languages, it is rarely possible to compare them with translations in other languages. It is also true that due to its privileged position as a working language French is the original language of most Court judgments. The authentic version of a judgment in another EU official language may thus be a more or less faithful translation of the French original. There is also a tendency to use equivalents that are externally close to the French original in EU translations (cf. sources cited in Mattila, 2013, p. 358, note 18). Thus, the real interpretation of provisions laying down general rules of EU laws is made in and through French (see also Doczekalska, 2006, p. 21; Fryźlewicz, 2008, pp. 52-53).

The equivalents used in the Polish translations of the judgments are presented in Table 1.

\subsubsection{Tort}

Tort law is the law of civil wrongs and it comprises numerous possible causes of action. In Black's Law Dictionary tort is defined in the common law system as a civil wrong for which a remedy may be obtained, usually in the form of damages, a breach of a duty that the law imposes on everyone in the same relation to one another as those involved in a given 
transaction (1999, p. 1496). It is also the branch of law dealing with such wrongs. The best known type of tort is the tort of negligence, which occurs when a person "fails to exercise due care." Some situations are defined by law as situations in which there exists a duty of care, i.e. the defendant should have taken reasonable care of the claimant or the claimant's rights or interests, which he/she failed to do, hence the claimant is suing him/her for a breach of the duty to exercise reasonable care.

The civil law concept of tort liability ('law of obligations') is, in contrast to the common law, a unified one as it covers all acts or situation which can give rise to rights or claims, and is customarily divided into three parts: the law of contracts, the law of tort (delict), and the law of unjust enrichment. Therefore the civil law is a law of tort rather than tort as a concept developed by the common law for redress for different kinds of harm (Glendon et al., 1985, p. 262; see also de Cruz, 2007, pp. 300301 and pp. 311-352 on other differences in a comparative perspective).

The distinction between contractual and delictual (tort) responsibility has been treated as fundamental in civil law theory, and is also reflected in the examples in Table 2 . However, there are many similarities in approach between civil law and common law jurisdictions, particularly in the requirement that a particular standard of care must be obligatory in order to find liability for unintentional harm (cf. the landmark case of Donoghue v Stevenson [1932] AC 562 where the tort of negligence was recognized in its modern sense). On the question of intentional harm, the common law has proceeded, as mentioned, by having specific torts, while Continental legal systems categorized particular groups of cases utilising a general cause (de Cruz, 2007, p. $350)$.

\subsubsection{Trust}

A legal 'trust' is a form of property law and can concern both tangible and intangible property. It is a legal arrangement whereby one person (the settlor) transfers property to another person (the trustee), who will hold it for the benefit of one or more persons (the beneficiary(ies)) (Oxford Dictionary of Law, 1994, p. 408). It can be created, for example, over property to be managed on behalf of a person who cannot hold a legal title to it, for example, a minor. Thus the trustee is the person who will hold legal title to the land until the minor (the beneficiary) becomes an adult. A trust must also be created when two or more persons want to own one piece of land or in order to arrange for the property to pass to family members in succession after the death of the owner. Trusts can be classified into two major types: express and implied trusts. Within the latter type a distinction can also be made into resulting trusts and constructive trusts. Express trusts are where the parties expressly agreed 
to create a trust in a written and signed document. An implied trust is found to exist when it is possible to infer the settlor's unexpressed intention. This can be inferred from the parties' conduct or the relationship between them.

In the contexts quoted below we have genuine common-law terms used in a classical common-law meaning, as the cases in question (mostly requests for a preliminary ruling) come from the United Kingdom, a common-law country, and, consequently, the term "trust" appears in the original documents of the national (common-law) courts.

The notion of trust is absent in the Polish legal system. Hence the original English term is frequently 'naturalized' into Polish legal terminology (see Table 3).

\subsubsection{Consideration}

Like 'trust', 'consideration' has both an ordinary meaning and is also a legal term. It is one of the essential and compulsory elements of a contract. Unlike the term 'trust' however, 'consideration' as a principle of contract law is almost wholly detached from its ordinary meaning.

Under modern English law, consideration is described as the price of the promise and involves some kind of detriment or benefit or both. It also must be of some kind of economic value in order to be legally significant. To a greater or lesser extent (for a variety of views see de Cruz, 2007, pp. 304-306) 'consideration resembles the Roman law notion of "cause" ("causa"). The doctrine of consideration began to be developed by the English courts in the mid-sixteenth century as a touchstone of the seriousness of contractual intention (de Cruz, 2007, p. 308). By the nineteenth century, de Cruz points out, consideration was entrenched in the doctrine of English law and became the pivotal prerequisite for the enforceability of a contract.

When one party gives something to the other party, i.e. sells goods or provides services, they are only entitled to 'payment' from the other party (whether monetary or in some other fashion) if there is sufficient consideration for the contract. Put simply, not every provision of goods or services is a contract. A gift is not a contract because no consideration was given by the donee (recipient of the gift), hence the donee cannot compel the donor to make the gift. Thus an alleged 'contract' can be declared void ab initio in the absence of sufficient consideration. It should be noted that it must be sufficient in the eyes of law, and that the courts will not investigate whether it is materially adequate and materially fair towards the other party. If the donee of a gift paid the sum of one dollar as 'consideration' (even if the 'gift' was worth much more) or agreed to refrain from a simple act in exchange for an expensive 'gift', the gift would be converted into a contractual transaction. The Oxford Dictionary of Law (1994, p. 86) defines consideration as an act, forbearance, or 
promise made by one party to a contract that constitutes the price for which he buys the act, forbearance, or promise of the other party.

\subsubsection{Misrepresentation}

Misrepresentation is also a term denoting a concept applied in contract law, defined as an untrue statement of fact made by one party, which induces the other party to enter into a contract (Oxford Dictionary of Law, 1994, p. 254). It is usually made with the intention to deceive the other party. A statement can be found to be misrepresentation only if it in fact induced the other party to enter into the contract, and a misrepresentation which does not induce another party to enter into a contract is not, legally speaking, an 'actionable' misrepresentation. There are different types of misrepresentation. A statement is found to be fraudulent misrepresentation if the misrepresentor (the person making the statement) knew it was false. An innocent misrepresentation is a statement which the misrepresentor honestly believed to be true and had reasonable grounds to believe so.

Another type is negligent misrepresentation, which occurs when the utterer believed in the truth of the statement but had no reasonable grounds to do so, or where there is a 'special relationship' giving rise to a duty of care between the parties. This English law notion may be compared with Roman law concept of culpa in contrahendo (de Cruz, 2007, pp. 323-324), which is also present in the Polish legal system. Such behaviour was not considered the basis for delictual/tortious liability, except for some rare cases, such as in Art. $387 \S 2$ of the Polish Civil Code, which reads as follows: "A party which, at the time of execution of a contract, was aware that performance was impossible and did not communicate this to the other party is obliged to remedy any damage the other party suffered by executing the contract while being unaware that performance was impossible". The Polish doctrine provides that the basis for legal action in such cases is the law of tort, and the scope of tort (ex delicto) liability is limited to damnum emergens and lucrum cessans ("ujemny interes umowy" in Polish). Other legal systems construe such liability as ex contractu liability by treating negotiations as a source of privity of contract (a relationship of obligation - "stosunek zobowiązaniowy" in Polish) (Kalina-Prasznic, 1999, p. 87).

\section{Conclusions}

The comparative law method of micro-comparison has proven very useful when translating legal institutions and concepts peculiar to another legal system. This micro-comparison of common law terms has also allowed for their quality assessment in terms of their equivalence and adequacy. 
The comparison of five English common law system-bound terms (equity, tort, trust, consideration, and misrepresentation) against their official Polish translations has shown some patterns in translator's choices.

The contrastive analysis of translations of European Court of Justice judgments has shown that translators in the ECJ, that is, lawyerlinguists, use predominantly functional equivalents, namely similar concepts if possible, with additional explanation and/or transcription. However, in some cases explanations do not appear to be informative enough. Such would appear to be the case with "odpowiedzialność deliktowa lub podobna" (literal back translation: "delictual or similar responsibility"). This might not convey to Polish legal specialists the same meaning as "responsibility in tort".

When there is no Polish concept for an English term and none can be treated as similar, the technique of borrowing or transcription/transferring has mostly been used, that is, the English term was directly transferred to the Polish target text. Such a solution was used particularly with the term 'trust', which could be recognized by Polish lawyers due to its long-time usage all over Europe.

Common law terms absent from the Polish legal system and not precise enough to create clear-cut equivalents have been rendered in various creative ways. This can be seen with respect to the terms 'misrepresentation' and 'consideration'. More than one term was adopted to convey the meaning of "misrepresentation' ("złożenie nieprawdziwych oświadczeń" - literally "give false testimony"; "wprowadzenie w bład" literally "lead someone to a mistaken understanding"). Both of these Polish renderings accurately reflected the meaning of 'misrepresentation' in the given instance, although the Polish reader might not be aware of the fact they referred to the same legal concept unless the English term 'misrepresentation' was also included in the text. Of the five examples taken into account, 'consideration' is probably the most complex legal concept, and while the Polish translations employed ("umowa o charakterze odptatnym" - literally "contract of a payment nature"; "umowa odptatna" - literally "a money contract") conveyed the meaning in context clearly enough, they would not help explain to a Polish lawyer the complexities of the term 'consideration'.

In the case of the term 'equity' one main equivalent was chosen and the discrepancies in the Polish versions of different documents/judgments were mostly due to changes in the context and sentence structure.

When no equivalent for a common law term was available in the Polish legal system, the nearest Polish concept was chosen, for example 'delikt' (delict) for 'tort', with possible additional qualifications and/or explanations to avoid misunderstandings. In the case of terms of foreign origin, such as the English 'trust', the technique of transferring is frequently used. This transfer of an original (foreign) term into the 
translated text would seem very useful for its correct understanding, and may give a chance to Polish legal professionals to adopt, if necessary, comparative law methods themselves.

Translations of ECJ judgments must thus be treated as approximate and not fully equivalent, especially when seeking equivalents for systembound terms (see also McAuliffe, 2009). The English-Polish translation combination, i.e. translation of a legal language used by common law jurisdictions into a legal language based on civil law traditions further complicates the process of translation, already complex by definition.

Hence, comparative law can be seen to constitute a useful tool and a proper means of understanding, comparing and assessing the equivalence of system-bound terms in legal translation. Recourse to comparative law provides both the background to and origin of legal rules and concepts (de Cruz, 2007, p. 21), and is an indispensible aid to a legal translator, especially one working in a multilingual environment.

\section{References}

Alcaraz Varó, E., \& Hughes, B. (2002). Legal translation explained. Manchester: St. Jerome.

Berteloot P. (1988). Babylone à Luxembourg, Jurilinguistique à la Cour de Justice. In G. Ress \& M. R. Will (Eds.), Vorträge, Reden und Berichte aus dem EuropaInstitut/No. 136 (pp. 1-32). Saarbrücken: Europa-Institut.

Black's Law Dictionary (1999). B. A. Garner (ed. in chief) (7th ed.). St. Paul, MN: West Group.

Bocquet C. (1994). Pour une méthode de traduction juridique. Prilly: CB Service.

Brand, O. (2009). Language as a barrier to comparative law. In F. Olsen, A. Lorz, \& D. Stein (Eds.), Translation issues in language and law (pp. 18-34). London: Palgrave Macmillan.

Brostoff T. K., \& Sinsheimer, A. (2000). An introduction to the legal language and culture of the United States. Dobbs Ferry, NY: Oceana.

Cao, D. (2007a). Translating law. Clevedon: Multilingual Matters.

Cao, D. (2007b). Inter-lingual uncertainty in bilingual and multilingual law. Journal of Pragmatics, 39, 69-83.

Cruz, P. de (2007). Comparative law in a changing world (3rd ed.). London: Routledge-Cavendish.

Dascal M., \& Wróblewski, J. (1991). The rational law-maker and the pragmatics of legal interpretation. Journal of Pragmatics, 15, 421-444.

David R., \& Brierley, J. (1985). Major legal systems in the world today (3rd ed.). London: Stevens.

Doczekalska, A. (2006). Interpretacja wielojęzycznego prawa Unii Europejskiej. Europejski Przeglad Sadowy, 5(8), 14-21.

Fryźlewicz, M. (2008). Znaczenie komparatystyki językowej w wykładni sądów luksemburskich. In C. Mik (Ed.), Wyktadnia prawa Unii Europejskiej (pp. 958). Toruń: Dom Organizatora. 
Glendon, M. A, Gordon, M. W., \& Osakwe, C. (1985). Comparative legal traditions: Text, materials and cases on the civil law, common law and socialist law traditions with special reference to French, West German, English and Soviet law. St. Paul, MN: West Publishing.

Grossfeld, B. (2003). Comparatists and languages. In P. Legrand \& R. Munday (Eds.), Traditions and transitions (pp. 154-194). Cambridge: Cambridge University Press.

Holland, J., \& Webb, J. (2006). Learning legal rules (6th ed.). Oxford: Oxford University Press.

Jopek-Bosiacka, A. (2011). Defining law terms: A cross-cultural perspective. Research in Language: A special issue on Legal Terminology. Approaches and Applications, 9(1), 9-29.

Jopek-Bosiacka, A. (2010). Legal communication: A cross-cultural perspective. Warsaw: Warsaw University Press.

Kalina-Prasznic, U. (Ed.). (1999). Encyklopedia prawa. Warsaw: C.H. Beck.

Kamba, W. (1974). Comparative law: A theoretical framework. International and Comparative Law Quarterly, 23(3), 485-519.

Kischel, U. (2009). Legal cultures - legal languages. In F. Olsen, A. Lorz, \& D. Stein (Eds.), Translation issues in language and law (pp. 7-17). London: Palgrave Macmillan.

Konic, L. (1947). Ogólne cechy „Equity”. Państwo i Prawo, 4(14), 30-40.

Kozak, A. (2002). Granice prawniczej wtadzy dyskrecjonalnej. Wrocław: Kolonia.

Lashöfer, J. (1992). Zum Stilwandel in richterlichen Entscheidungen. Münster: Waxmann.

Łętowska, E. (1997). Pozaprocesowe znaczenie uzasadnienia sądowego. Państwo $i$ Prawo, 5, 3-17.

Mattila, H. E. S. (2013). Comparative legal linguistics (2nd ed.). Aldershot: Ashgate.

McAuliffe, K. (2009). Translation of the European Court of Justice of the European Communities. In F. Olsen, A. Lorz, \& D. Stein (Eds.), Translation issues in language and law (pp. 99-115). London: Palgrave Macmillan.

Mik, C. (2000). Europejskie prawo wspólnotowe: Zagadnienia teorii i praktyki. Vol. 1. Warsaw: C. H. Beck.

Newmark, P. (1981). Approaches to translation. Oxford: Pergamon.

Mimin, P. (1978). Le style des jugements. Paris: Librairies techniques.

Orücü E. (2006). Methodology of comparative law. In J. Smits (Ed.), Elgar encyclopedia of comparative law (pp. 442-454). Cheltenham: Edward Elgar.

Oxford Dictionary of Law (1994). Edited by E. A. Martin (3rd ed.). Oxford: Oxford University Press.

Piętka, H. (1929). Stuszność w teorji i praktyce. Warsaw: Wydawnictwo Seminarium Encyklopedii i Filozofji Prawa nr 2.

Rheinstein M. (1968). Comparative law: Its functions, methods and usages. Arkansas Law Review and Bar Association Journal, 22(3).

Šarčević, S. (1997). New approach to legal translation. The Hague: Kluwer Law International. 
Šarčević, S. (1988). Translation of legislation - with special emphasis on languages of limited diffusion. In P. Nekeman (Ed.), Translation, our Future. XIth World Congress of FIT (pp. 455-462). Maastricht: Euroterm.

Walker, D. M. (1980). The Oxford companion to law. Oxford: Clarendon.

Weisflog, W. E. (1987). Problems of legal translation. Swiss reports presented at the XIIth International Congress of Comparative Law (pp. 179-218). Zurich: Schulthess.

Wetter, J. G. (1960). The styles of appellate judicial opinions: A case study in comparative law. Layden: Sythoff.

Zweigert, H., \& Kötz, H. (1977). An introduction to comparative law. Vols I and II. Oxford: Clarendon. 
Table 1: Polish equivalents of 'equity'

\begin{tabular}{|c|c|c|c|c|c|}
\hline English & Polish & $\begin{array}{l}\text { Context } \\
\text { (English) }\end{array}$ & Context (Polish) & Back translation (literal) & Case \\
\hline $\begin{array}{l}\text { criterion of } \\
\text { equity }\end{array}$ & $\begin{array}{l}\text { zasada } \\
\text { słuszności }\end{array}$ & $\begin{array}{l}\text { for the purposes of the application } \\
\text { of the criterion of equity }\end{array}$ & $\begin{array}{l}\text { w ramach stosowania kryterium } \\
\text { zgodności z zasadami stuszności }\end{array}$ & $\begin{array}{l}\text { 'criterion of equity' } \\
\text { is translated as 'criterion in } \\
\text { accordance with the } \\
\text { principles of what is 'due } \\
\text { and just' }\end{array}$ & $\begin{array}{l}\text { C-348/07 } \\
\text { Turgay } \\
\text { Semen v } \\
\text { Deutsche } \\
\text { Tamoil GmbH }\end{array}$ \\
\hline $\begin{array}{l}\text { criterion of } \\
\text { equity }\end{array}$ & $\begin{array}{l}\text { kryterium } \\
\text { słuszności }\end{array}$ & $\begin{array}{l}\text { the Member States enjoy a margin } \\
\text { of discretion which they may } \\
\text { exercise, in particular, in relation to } \\
\text { the criterion of equity }\end{array}$ & $\begin{array}{l}\text { państwom członkowskim } \\
\text { przysługuje swoboda uznania, z } \\
\text { której moga korzystać w } \\
\text { szczególności z uwzględnieniem } \\
\text { kryterium stuszności }\end{array}$ & $\begin{array}{l}\text { 'in relation to the criterion } \\
\text { of equity' is translated as } \\
\text { 'taking into account the } \\
\text { criterion of what is 'due } \\
\text { and just' }\end{array}$ & $\begin{array}{l}\text { C-465-04 } \\
\text { Honyvem } \\
\text { Informazioni } \\
\text { Commerciali Srl v } \\
\text { Mariella De Zotti }\end{array}$ \\
\hline
\end{tabular}




\begin{tabular}{|c|c|c|c|c|c|}
\hline $\begin{array}{l}\text { principle of } \\
\text { equity }\end{array}$ & $\begin{array}{l}\text { zasada } \\
\text { słuszności }\end{array}$ & $\begin{array}{l}\text { The last indent of Article } 33(2)(\ldots) \\
\text { appears (...) to express a general } \\
\text { principle of equity }\end{array}$ & $\begin{array}{l}\text { Artykuł } 33 \text { ust. } 2 \text { (...) wydaje się } \\
\text { być (...) klauzulą generalną opartą } \\
\text { na zasadzie stuszności }\end{array}$ & $\begin{array}{l}\text { Article } 33 \text { appears to be a } \\
\text { general clause based on the } \\
\text { principle of what is due } \\
\text { and just }\end{array}$ & $\begin{array}{l}\text { C-375/05 Erhard } \\
\text { Geuting v } \\
\text { Direktor der } \\
\text { Landwirtschafts- } \\
\text { kammer } \\
\text { Nordrhein- } \\
\text { Westfalen für den } \\
\text { Bereich } \\
\text { Landwirtschaft }\end{array}$ \\
\hline equity & sprawiedliwość & $\begin{array}{l}\text { Equity and the principle of } \\
\text { proportionality require that } \\
\text { undertakings are not placed under } \\
\text { the same footing }\end{array}$ & 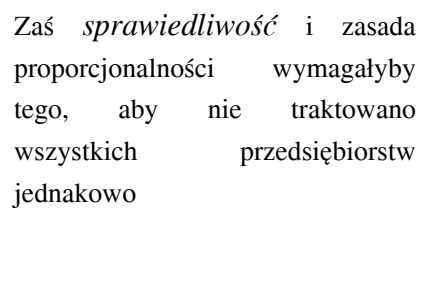 & $\begin{array}{l}\text { Justice and the principle of } \\
\text { proportionality... }\end{array}$ & $\begin{array}{l}\text { T- } 44 / 00 \\
\text { Mannesmannröhren- } \\
\text { Werke AG v } \\
\text { Commission of the } \\
\text { European } \\
\text { Communities }\end{array}$ \\
\hline
\end{tabular}


Table 2: Polish equivalents of 'tort'

\begin{tabular}{|c|c|c|c|c|c|}
\hline English & Polish & Context (English) & Context (Polish) & Back translation (literal) & Case \\
\hline in tort & (z) deliktu & $\begin{array}{l}\text { In the carriage of passengers, } \\
\text { baggage and cargo, any action } \\
\text { for damages, however } \\
\text { founded, whether under this } \\
\text { Convention or in contract or in } \\
\text { tort or otherwise, can only be } \\
\text { brought subject to the } \\
\text { conditions (...) }\end{array}$ & $\begin{array}{l}\text { W przewozie osób, bagażu i ładunku } \\
\text { jakiekolwiek powództwo dla uzyskania } \\
\text { odszkodowania, jakkolwiek uzasadnione, } \\
\text { zarówno na podstawie niniejszej } \\
\text { konwencji, jak i z umowy lub deliktu, } \\
\text { może zostać wszczęte wyłącznie } \\
\text { z zastrzeżeniem warunków (...) }\end{array}$ & $\begin{array}{l}\text { In the carriage of passengers, } \\
\text { baggage and cargo, any action } \\
\text { for damages, however } \\
\text { founded, whether under this } \\
\text { Convention or in contract or } \\
\text { in delict or otherwise, can } \\
\text { only be brought subject to the } \\
\text { conditions (...) }\end{array}$ & $\begin{array}{l}\text { C-12/11 } \\
\text { Denise McDonagh } \\
\text { v Ryanair Ltd. }\end{array}$ \\
\hline tort & czyn niedozwolony & $\begin{array}{l}\text { in matters relating to tort, } \\
\text { delict or quasi-delict, in the } \\
\text { courts for the place where the } \\
\text { harmful event occurred or may } \\
\text { occur }\end{array}$ & $\begin{array}{l}\text { jeżeli przedmiotem postępowania jest } \\
\text { czyn niedozwolony lub czyn podobny } \\
\text { do czynu niedozwolonego albo } \\
\text { roszczenia wynikajqce z takiego } \\
\text { czynu - przed sąd miejsca, gdzie } \\
\text { nastąpiło lub może nastąpić zdarzenie } \\
\text { wywołujące szkodę }\end{array}$ & $\begin{array}{l}\text { 'if the subject of the } \\
\text { proceedings is a prohibited } \\
\text { action or an action similar to a } \\
\text { prohibited action or a claim } \\
\text { arising from such an action in } \\
\text { the courts ... }\end{array}$ & $\begin{array}{l}\text { C-185/07 Allianz } \\
\text { SpA and Generali } \\
\text { Assicurazioni } \\
\text { Generali } \\
\text { SpA v West Tankers } \\
\text { Inc. (citation from } \\
\text { Regulation No. } \\
\text { 44/2001) }\end{array}$ \\
\hline
\end{tabular}




\begin{tabular}{|c|c|c|c|c|c|}
\hline $\begin{array}{l}* \text { relating } \\
\text { to a } \\
\text { contract, } \\
\text { or to tort } \\
\text { or delict }\end{array}$ & $\begin{array}{l}\text { sprawy } \\
\text { charakterze } \\
\text { deliktowym }\end{array}$ & $\begin{array}{l}\text { whether in matters relating to a } \\
\text { contract, or to tort or delict, or } \\
\text { any other matter }\end{array}$ & $\begin{array}{l}\text { czy to } \quad \text { o } \quad \text { charakterze } \\
\text { zobowiązaniowym, deliktowym } \text { czy też } \\
\text { innym }\end{array}$ & $\begin{array}{l}\text { 'whether in the nature of an } \\
\text { obligation or a delictual } \\
\text { obligation }\end{array}$ & $\begin{array}{l}\text { C-372/07 Nicole } \\
\text { Hassett v South } \\
\text { Eastern Health Board } \\
\text { And Cheryl Doherty } \\
\text { v North Western } \\
\text { Health Board }\end{array}$ \\
\hline $\begin{array}{l}\text { tort, delict } \\
\text { or quasi- } \\
\text { delict }\end{array}$ & $\begin{array}{l}\text { odpowiedzialność } \\
\text { deliktowa lub } \\
\text { podobna }\end{array}$ & $\begin{array}{l}\text { The action (...) was based in } \\
\text { tort, delict or quasi-delict }\end{array}$ & $\begin{array}{lrrr}\text { powództwo jest } & \text { oparte } & \text { na } \\
\text { odpowiedzialności } & \text { deliktowej } & \text { lub } \\
\text { podobnej } & & \end{array}$ & $\begin{array}{l}\text { The action }(\ldots) \text { was based on } \\
\text { delictual or similar } \\
\text { responsibility }\end{array}$ & $\begin{array}{l}\text { C-98/06 Freeport plc } \\
\text { v Olle Amoldsson }\end{array}$ \\
\hline
\end{tabular}




\begin{tabular}{|c|c|c|c|c|c|}
\hline & & liability in tort or delict & odpowiedzialność deliktowa & delictual liability & \\
\hline $\begin{array}{l}\text { the } \\
\text { concept of } \\
\text { tort }\end{array}$ & $\begin{array}{l}\text { pojęcie czynu } \\
\text { niedozwolonego }\end{array}$ & $\begin{array}{l}\text { 58. Whilst any attempt to } \\
\text { provide a comprehensive } \\
\text { definition of the concept of } \\
\text { 'tort', delict or quasi-delict' } \\
\text { based on the laws of the } \\
\text { Contracting States would be } \\
\text { problematic, (22) it is possible } \\
\text { to identify certain generally } \\
\text { recurring features. }\end{array}$ & $\begin{array}{l}\text { O ile jakakolwiek próba sformułowania } \\
\text { ogólnej definicji pojęcia „czynu } \\
\text { niedozwolonego lub czynu podobnego } \\
\text { do czynu niedozwolonego albo } \\
\text { roszczenia wynikającego z tego czynu” } \\
\text { w oparciu o przepisy obowiązujące w } \\
\text { umawiających się państwach byłaby } \\
\text { problematyczna(22), możliwe jest jednak } \\
\text { określenie pewnych ogólnie } \\
\text { powtarzających się cech. }\end{array}$ & $\begin{array}{l}\text { Whilst any attempt to provide } \\
\text { a comprehensive definition of } \\
\text { the concept of 'tort', delict } \\
\text { or quasi-delict' based on the } \\
\text { laws of the Contracting States } \\
\text { would be problematic, (22) it } \\
\text { is possible to identify certain } \\
\text { generally recurring features. }\end{array}$ & $\begin{array}{l}\text { C-27/02 Petra Engler } \\
\text { v Janus Versand } \\
\text { GmbH } \\
\text { (English-language } \\
\text { opinion of Attorney } \\
\text { General Jacobs of } 8 \\
\text { July 2002) }\end{array}$ \\
\hline
\end{tabular}


Table 3. Polish equivalents of 'trust'

\begin{tabular}{|c|c|c|c|c|c|}
\hline English & Polish & Context (English) & Context (Polish) & Back translation (literal) & Case \\
\hline
\end{tabular}




\begin{tabular}{|c|c|c|c|c|c|}
\hline & & $\begin{array}{l}\text { constituted under statute both } \\
\text { come within the scope of that } \\
\text { provision. }\end{array}$ & $\begin{array}{l}\text { zbiorowego } \\
\text { inwestowania w papiery } \\
\text { wartościowe działajqce } \\
w \text { formie umownej, } \\
\text { trustu, jak i te działające } \\
\text { w formie statutowej }\end{array}$ & $\begin{array}{l}\text { collective investing in } \\
\text { securities acting in the } \\
\text { form of a trust... }\end{array}$ & $\begin{array}{l}\text { Fund v Commissioners } \\
\text { of Customs \& Excise }\end{array}$ \\
\hline unit trust & $\begin{array}{l}\text { fundusz } \\
\text { powierniczy }\end{array}$ & $\begin{array}{l}\text { transactions involving unit } \\
\text { trust's assets }\end{array}$ & $\begin{array}{l}\text { Transakcj[e] zwiazan[e] } \\
\mathrm{z} \text { aktywami funduszu } \\
\text { powierniczego }\end{array}$ & $\begin{array}{l}\text { Transactions involving } \\
\text { the assets of a trust fund }\end{array}$ & $\begin{array}{l}\text { C-169/04 Abbey } \\
\text { National plc and } \\
\text { Inscape Investment } \\
\text { Fund v Commissioners } \\
\text { of Customs \& Excise }\end{array}$ \\
\hline $\begin{array}{l}\text { authorised unit } \\
\text { trusts }\end{array}$ & $\begin{array}{l}\text { posiadające } \\
\text { zezwolenie } \\
\text { przedsiębiortstwa } \\
\text { zbiorowego } \\
\text { inwestowania } \\
\text { mające formę trustu }\end{array}$ & $\begin{array}{l}\text { concerning the taxation of } \\
\text { services supplied by the } \\
\text { depositaries of a number of } \\
\text { authorised unit trusts }\end{array}$ & $\begin{array}{lr}\text { w } & \text { przedmiocie } \\
\text { opodatkowania } & \text { z jednej } \\
\text { strony } & \text { usług } \\
\text { świadczonych } & \text { przez } \\
\text { depozytariuszy } & \\
\text { określonej } & \text { liczby } \\
\text { posiadających } & \\
\text { zezwolenie } & \\
\text { przedsiębiorstw } & \end{array}$ & $\begin{array}{l}\text { concerning the taxation } \\
\text { on the one hand of } \\
\text { services supplied by } \\
\text { depositaries of a defined } \\
\text { number of enterprise } \\
\text { possessing the right of } \\
\text { collective investment } \\
\text { in the form of a trust } \\
\text { " "authorised unit }\end{array}$ & $\begin{array}{l}\text { C-169/04 Abbey } \\
\text { National plc and } \\
\text { Inscape Investment } \\
\text { Fund v Commissioners } \\
\text { of Customs \& Excise }\end{array}$ \\
\hline
\end{tabular}




\begin{tabular}{|c|c|c|c|c|c|}
\hline & & & $\begin{array}{l}\text { zbiorowego } \\
\text { inwestowania mających } \\
\text { formę trustu (,authorised } \\
\text { unit trusts") }\end{array}$ & trusts") & \\
\hline $\begin{array}{l}\text { authorised unit } \\
\text { trusts }\end{array}$ & $\begin{array}{l}\text { Transferring (using } \\
\text { original term) }\end{array}$ & $\begin{array}{l}\text { According to the FSMA, an } \\
\text { authorised unit trust is a } \\
\text { collective investment scheme } \\
\text { under which the property is } \\
\text { held on trust for the } \\
\text { participants and which is } \\
\text { authorised by an authorisation } \\
\text { order. }\end{array}$ & 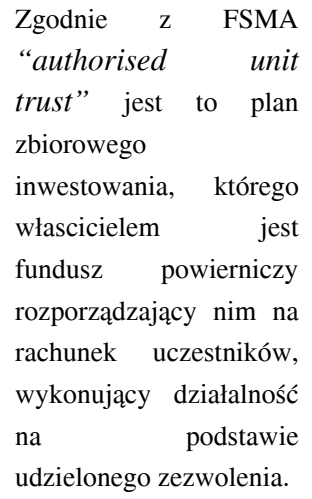 & $\begin{array}{l}\text { According to the FSMA, } \\
\text { an "authorised unit } \\
\text { trust" is a collective } \\
\text { investment in which the } \\
\text { owner is a trust fund } \\
\text { managing the fund on } \\
\text { account for participants } \\
\text { on the basis of an } \\
\text { authorisation given by } \\
\text { the participants. }\end{array}$ & $\begin{array}{l}\text { C-169/04 Abbey } \\
\text { National plc and } \\
\text { Inscape Investment } \\
\text { Fund v Commissioners } \\
\text { of Customs \& Excise }\end{array}$ \\
\hline
\end{tabular}


Table 4: Polish equivalents of 'consideration'

\begin{tabular}{|c|c|c|c|c|c|}
\hline English & Polish & Context (English) & Context (Polish) & Back translation (literal) & Case \\
\hline for consideration & odpłatnie & $\begin{array}{l}\text { Article 2(1) of the Sixth } \\
\text { Directive makes subject } \\
\text { to VAT 'the supply of } \\
\text { goods or services } \\
\text { effected for } \\
\text { consideration within } \\
\text { the territory of the } \\
\text { country by a taxable } \\
\text { person acting as such'. }\end{array}$ & $\begin{array}{l}\text { Na podstawie art. } 2 \text { pkt } 1 \\
\text { szóstej dyrektywy } \\
\text { opodatkowaniu } \\
\text { podatkiem VAT podlega } \\
\text { „dostawa towarów lub } \\
\text { usług śrwiadczona } \\
\text { [świadczenie usług } \\
\text { dokonywane] odptatnie } \\
\text { na terytorium kraju przez } \\
\text { podatnika, który jako } \\
\text { taki występuje } \\
\text { [działającego w takim } \\
\text { charakterze]”. }\end{array}$ & $\begin{array}{l}\text { Article 2(1) of the Sixth } \\
\text { Directive makes subject to } \\
\text { VAT 'the supply of goods or } \\
\text { services effected for } \\
\text { remuneration within the } \\
\text { territory of the country by a } \\
\text { taxable person acting as } \\
\text { such'. }\end{array}$ & $\begin{array}{l}\text { C-653/11 } \\
\text { Her Majesty's } \\
\text { Commissioners of } \\
\text { Revenue and } \\
\text { Customs } \\
\text { v Paul Newey. }\end{array}$ \\
\hline for consideration & odpłatnie & $\begin{array}{l}\text { VAT is to be levied on } \\
\text { all goods or services } \\
\text { supplied for } \\
\text { consideration by a } \\
\text { taxable person }\end{array}$ & $\begin{array}{lrr}\text { podatek VAT } & \text { jest } \\
\text { pobierany od każdej } \\
\text { dostawy towarów lub } \\
\text { świadczenia r usług } \\
\text { dokonanego odptatnie }\end{array}$ & $\begin{array}{l}\text { VAT is to be levied on all } \\
\text { goods or services executed } \\
\text { for remuneration by a } \\
\text { taxable person }\end{array}$ & $\begin{array}{l}\text { C-572/07 RLRE } \\
\text { Tellmer Property sro } \\
\text { V Finančni řerditelstvi } \\
\text { v Ǔsti nad Labem }\end{array}$ \\
\hline
\end{tabular}




\begin{tabular}{|c|c|c|c|c|c|}
\hline & & & przez podatnika & & \\
\hline for consideration & odpłatne & $\begin{array}{l}\text { to make available such } \\
\text { cars (vehicles) for use } \\
\text { for consideration } \\
\text { under a hire }\end{array}$ & $\begin{array}{lr}\text { oddanie w } & \text { odptatne } \\
\text { używanie } & \text { tych } \\
\text { samochodów (pojazdów) } \\
\text { na podstawie umowy } \\
\text { najmu }\end{array}$ & $\begin{array}{l}\text { to make available such cars } \\
\text { (vehicles) for use on a } \\
\text { payment basis under a hire }\end{array}$ & $\begin{array}{l}\text { C-414/07 Magoora } \\
\text { Sp. z o.o. v. } \\
\text { Dyrektor Izby } \\
\text { Skarbowej w Krakowie }\end{array}$ \\
\hline consideration & wynagrodzenie & $\begin{array}{l}\text { consideration for the } \\
\text { provision of services }\end{array}$ & $\begin{array}{l}\text { wynagrodzenie } \quad \text { za } \\
\text { świadczenie usług }\end{array}$ & $\begin{array}{l}\text { remuneration for the } \\
\text { provision of services }\end{array}$ & $\begin{array}{l}\text { C-300/07 Hans \& } \\
\text { Christophorus } \\
\text { Oymanns GbR, } \\
\text { Ortopädie } \\
\text { Schuhtechnik v AOK } \\
\text { Rheinland/Hamburg }\end{array}$ \\
\hline $\begin{array}{l}\text { in consideration } \\
\text { for }\end{array}$ & w zamian za & $\begin{array}{l}\text { in consideration for } \\
\text { the according of special } \\
\text { commercial or financial }\end{array}$ & $\begin{array}{l}w \quad \text { zamian } z a \\
\text { przyznanie szczególnych } \\
\text { korzyści } \\
\text { gospodarczych }\end{array}$ & $\begin{array}{llr}\text { in exchange } & \text { for the } \\
\text { according of } & \text { special } \\
\text { commercial } & \text { or } & \text { financial }\end{array}$ & $\begin{array}{l}\text { C-260/07 Pedro IV } \\
\text { Servicios SL v Total } \\
\text { Espana SA }\end{array}$ \\
\hline
\end{tabular}




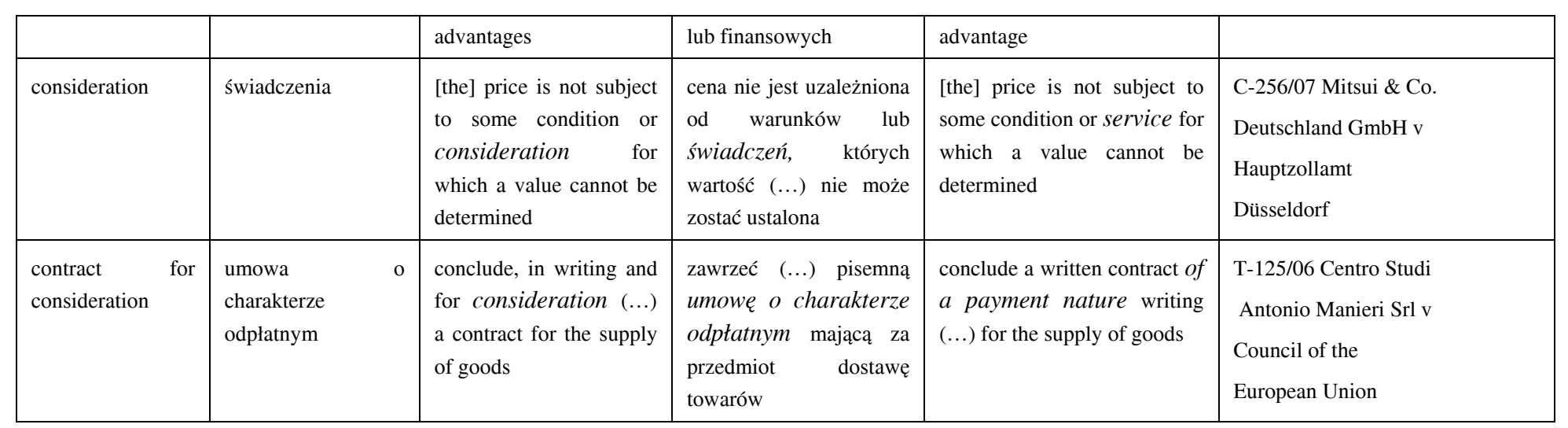


Table 5: Polish equivalents of 'misrepresentation'

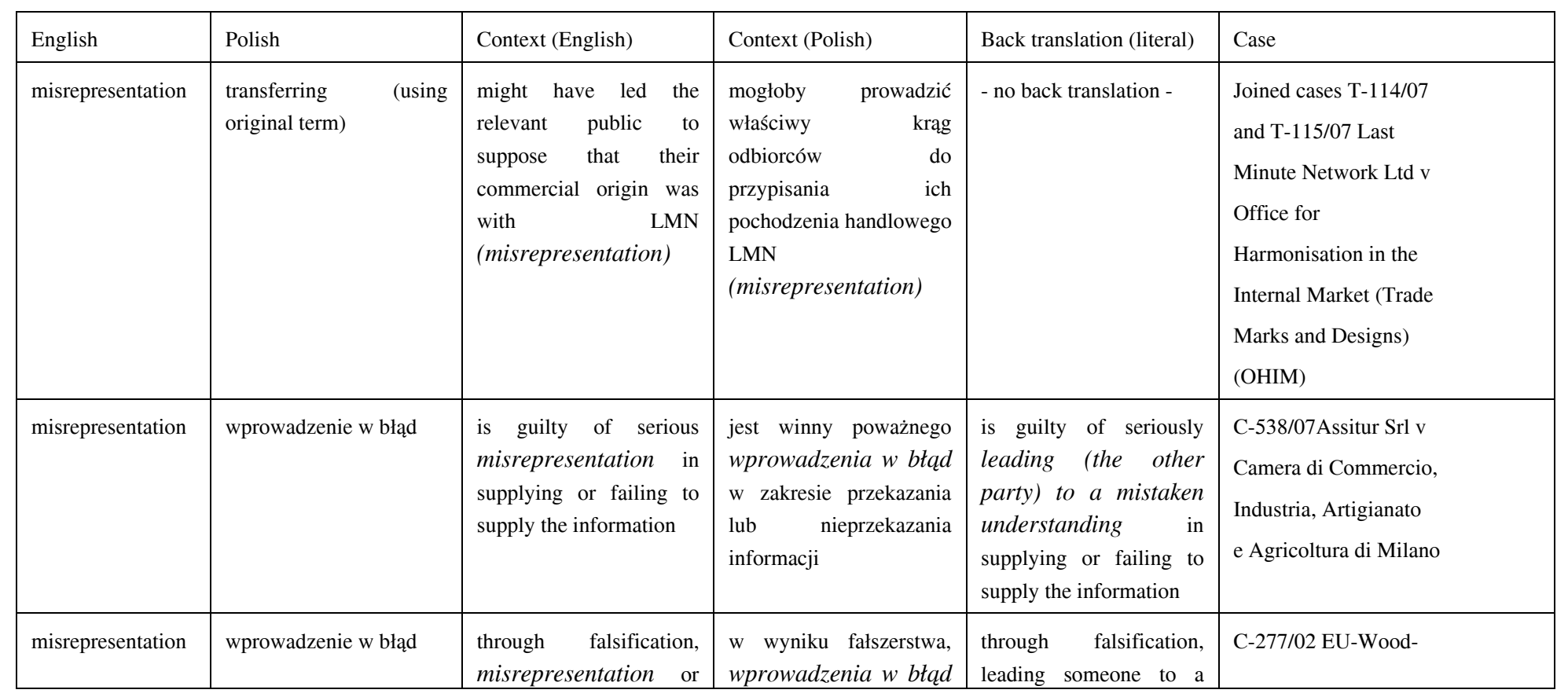




\begin{tabular}{|l|l|l|l|l|l|}
\hline & & fraud nadużycia & $\begin{array}{l}\text { mistaken understanding, } \\
\text { or fraud }\end{array}$ & $\begin{array}{l}\text { Trading GmbH } \mathrm{v} \\
\text { Sonderabfall- } \\
\text { Management- } \\
\text { Gesellschaft } \\
\text { Rheinland -Pfalz }\end{array}$ \\
\hline GmbH
\end{tabular}




\begin{tabular}{|c|c|c|c|c|c|}
\hline & & & & & European Communities \\
\hline misrepresentation & $\begin{array}{l}\text { nieprawidłowe } \\
\text { przedstawienie }\end{array}$ & $\begin{array}{l}\text { Misrepresentation of } \\
\text { the Decision in the } \\
\text { application }\end{array}$ & $\begin{array}{l}\text { nieprawidłowe } \\
\text { przedstawienie decyzji w } \\
\text { skardze }\end{array}$ & $\begin{array}{l}\text { False presentation of } \\
\text { the Decision in the } \\
\text { application }\end{array}$ & $\begin{array}{l}\text { T-464/04 Independent } \\
\text { Music Publishers and } \\
\text { Labels Association } \\
\text { (Impala, association } \\
\text { internationale) v } \\
\text { Commission of the } \\
\text { European Communities }\end{array}$ \\
\hline misrepresentation & błędne przedstawienie & $\begin{array}{l}\text { The Joint Declaration } \\
\text { (..) is not a clear } \\
\text { misrepresentation of } \\
\text { reality }\end{array}$ & $\begin{array}{l}\text { Wspólnej deklaracji (...) } \\
\text { nie można uznać za } \\
\text { oczywiście btędne } \\
\text { przedstawienie } \\
\text { okoliczności faktycznych }\end{array}$ & $\begin{array}{l}\text { The Joint Declaration } \\
(\ldots) \text { cannot be } \\
\text { considered as a clearly } \\
\text { wrongful presentation } \\
\text { of the circumstances }\end{array}$ & $\begin{array}{l}\text { C-347/03 Regione } \\
\text { autonoma Friuli- } \\
\text { Venezia Giulia and } \\
\text { Agenzia regionale per } \\
\text { lo sviluppo rurale } \\
\text { (ERSA) v } \\
\text { Ministero delle } \\
\text { Politiche Agricole e } \\
\text { Forestali }\end{array}$ \\
\hline
\end{tabular}




\begin{tabular}{|c|c|c|c|c|c|}
\hline misrepresentation & $\begin{array}{l}\text { złożenie } \\
\text { nieprawdziwych } \\
\text { oświadczeń }\end{array}$ & $\begin{array}{lr}\text { are guilty } & \text { of } \\
\text { misrepresentation } & \text { in } \\
\text { supplying } & \text { the } \\
\text { information } & \end{array}$ & $\begin{array}{ll}\text { są winni złożenia } \\
\text { nieprawdziwych } & \\
\text { oświadczeń } & \text { przy } \\
\text { przedstawianiu } & \\
\text { informacji } & \end{array}$ & $\begin{array}{l}\text { are guilty of giving a } \\
\text { false statement in } \\
\text { supplying } \\
\text { information }\end{array}$ & $\begin{array}{l}\text { Joined cases T-376/05 } \\
\text { And T-383/05 TEA- } \\
\text { CEGOS, SA, Services } \\
\text { Techniques globaux } \\
\text { (STG) SA (T-376/05) } \\
\text { and GHK Consulting } \\
\text { Ltd (T-383/05) v } \\
\text { Commission of the } \\
\text { European Communities }\end{array}$ \\
\hline
\end{tabular}


1 Comparative law, as defined by the authoritative Black's Law Dictionary (1999), B.A. Garner (editor in chief), 7th edition, St. Paul, Minn.: West Group under an entry 'comparative jurisprudence' (p. 858). For other names, see e.g. De Cruz (2007, p. 5).

2 The distinctive judicial styles enumerated by de Cruz (2007), following Wetter (1960), refer to the appellate level, as he argues that first-instance judgments are frequently laconic. We believe that this typology is relevant for the discussion of ECJ judgments as firstly, their structure is complex, and secondly, they are final and binding on the member states.

3 Section 3 is written predominantly on the basis of the information available on the ECJ official website: http://curia.europa.eu as it contains most current data (site visited on 2 July 2013).

4 The Civil Code / Kodeks cywilny, translation Ewa Kucharska, language consultant Michele Le Mauviel, Warszawa: C.H. Beck, 2011. 